\title{
Endoscopic dacryocystorhinostomy with an otologic T-type ventilation tube in repeated revision cases
}

\author{
Sihai Wu, Ting Xu, Bin Fan and Dajiang Xiao*
}

\begin{abstract}
Background: To compare the frequency of appearance of complications, anatomical success and functional success after conventional endoscopic dacryocystorhinostomies (EN-DCRs) or EN-DCR with otologic T-Type ventilation tube combined with silicone tube intubation in repeated revision cases.
\end{abstract}

Methods: Twenty-two patients who had epiphora and recurrent dacryocystitis after at least a previous failed revision DCR as well as 22 patients receiving conventional EN-DCR only were enrolled in the study between January 2008 and December 2011. Operations were performed by using an otologic T-tube combined with silicone tube intubation. Oral antibiotics, nasal steroids, oral antihistamines, and antibiotic eyedrops were given to all cases. The ventilation tubes were removed 6 to 20 weeks after surgery.

Results: Of 22 cases, all cases achieved anatomical success, 19 cases were symptom free, and 3 cases had decreased continuation in complications with a functional success rate of $81.8 \%$. The overall success rates were significantly higher than those in patients undertaking conventional EN-DCR only $(P<0.01)$.

Conclusion: The revision endoscopic DCR has a high rate of failure. The usage of a T-type ventilation tube can significantly improve the success rate of surgery.

Trial registration number: ChiCTR-INR-17012160, retrospectively registered on July 27th, 2017.

Keywords: Endoscopic dacryocystorhinostomy, T-type ventilation tube, Chronic dacryocystitis, Clinical efficacy

\section{Background}

It has been reported that endonasal dacryocystorhinostomies (EN-DCRs) yields good esthetic, functional results and similar success rate to that of the external dacryocystorhinostomies (EX-DCRs) [1-5]. By simulating EX-DCRs in EN-DCRs (mainly in two aspects: 1 maximizing bone window and complete exposure of the inside wall of larimal sac; 2 Ensuring anatomical overlap of the lacrimal sac and nasal mucosal flap), the ENDCRs can achieve similar successful rates to EX-DCRs $[6,7]$. But for the cases of small sac who have lacrimal sac mucosa fibrosis and mucosa scarring resulting from limited residual sac mucosa caused by previous DCRs, the success rate of revision DCR is significantly reduced

\footnotetext{
* Correspondence: dajiangxiao2016@sina.cn

Department of Otorhinolarynogology, The Second People's Hospital of Wuxi,
Nanjing Medical University, NO. 68, Zhongshan Road Wuxi, Nanjing, Jiangsu

Department of Otorhinolarynogology, The Second People's Hospital of Wuxi, 214002, China
}

(c) The Author(s). 2017 Open Access This article is distributed under the terms of the Creative Commons Attribution 4.0 International License (http://creativecommons.org/licenses/by/4.0/), which permits unrestricted use, distribution, and reproduction in any medium, provided you give appropriate credit to the original author(s) and the source, provide a link to the Creative Commons license, and indicate if changes were made. The Creative Commons Public Domain Dedication waiver (http://creativecommons.org/publicdomain/zero/1.0/) applies to the data made available in this article, unless otherwise stated. the most important reasons is that it is difficult to form lacrimal sac mucosal flap and nasal mucosa flap anatsatomosis, which causes stoma scarring and resultant surgical failure. Those patients often require repeated revision DCRs, and the revision DCRs often require special surgical approach such as agger nasi cell mucosal autograft for lacrimal sac reconstruction or mucosal grafting $[10,11]$. A recent retrospective review has reported that powered EN-DCR is a suitable option for revising failed DCRs in which yields good long-term results [3]. Inserting silicone tubes through the inferior and the superior puncta significantly improved the successful rate of revision DCR $[2,4]$. However, silicone tubes were too thin to induce the closure of newly performed ostia for patients with the risk factors of failure. To improve the current EN-DCR procedure, we have inserted an 
otologic T-type tube in addition to silicone tube into the lacrimal sac cavity., and we have achieved a higher success rate than conventional EN-DCR with careful treatment after surgery.

\section{Methods}

\section{Patients}

This is a prospective study where 22 patients who had previously undergone at least once failed EN-DCR were enrolled in our study during January 2008 to December 2011. The main symptoms of all patients were epiphora. All patients were given a detailed ophthalmic and otolaryngologic examination preoperatively. The former included lacrimal probe and rinse to eliminate canalicular and tear duct obstruction. The latter included a detailed nasal endoscopy to determine whether there were nasal abnormalities such as high deviated septum, which might influence the surgery effect [12]. All the operations, including the last revision DCR, were performed by the same surgeon. In addition, 22 patients who received conventional EN-DCR only were included as control.

The study was approved by the Ethical Committee of The Second People's Hospital of Wuxi. Informed consents were obtained from all individuals included in the study.

\section{Surgical technique}

EN-DCR was performed under general anesthesia. After decongestion and vasoconstriction of the nasal mucosa with packing of $1 / 1000$ adrenaline solution, an elbow probe was used to determine the exact location of the last bone window. Under endoscopic visualization with a $30^{\circ}$ endoscope, a curved mucosal flap incision was carried $0.5 \mathrm{~cm}$ more anteriorly over the front edge of bone window. When necessary, the bone window was enlarged with a $15^{\circ}$ medtronic sac drill until complete sac exposure was obtained including inside wall. A lacrimal probe was inserted through the inferior punctum into sac, the median wall of the sac was pushed into the nasal cavity. The medial $1^{*} 1 \mathrm{~cm}$ section of the median wall of the lacrimal sac was excised upon the mucosal incision with the sickled blade. Silicone tube needles which were inserted through the inferior and the superior puncta were grasped in the nasal cavity, followed by the insertion of the T-type ventilation tube using micro-alligator forceps, which were commonly used in ear surgery (Fig. 1). T-type ventilation tube was set out of the silicone tube when assistant pulled the two ends of the silicone tube. A gun-shaped clamp was used to make the T-type tube gradually sliding towards the sac. Two feet of T-tube was unfolded into sac with
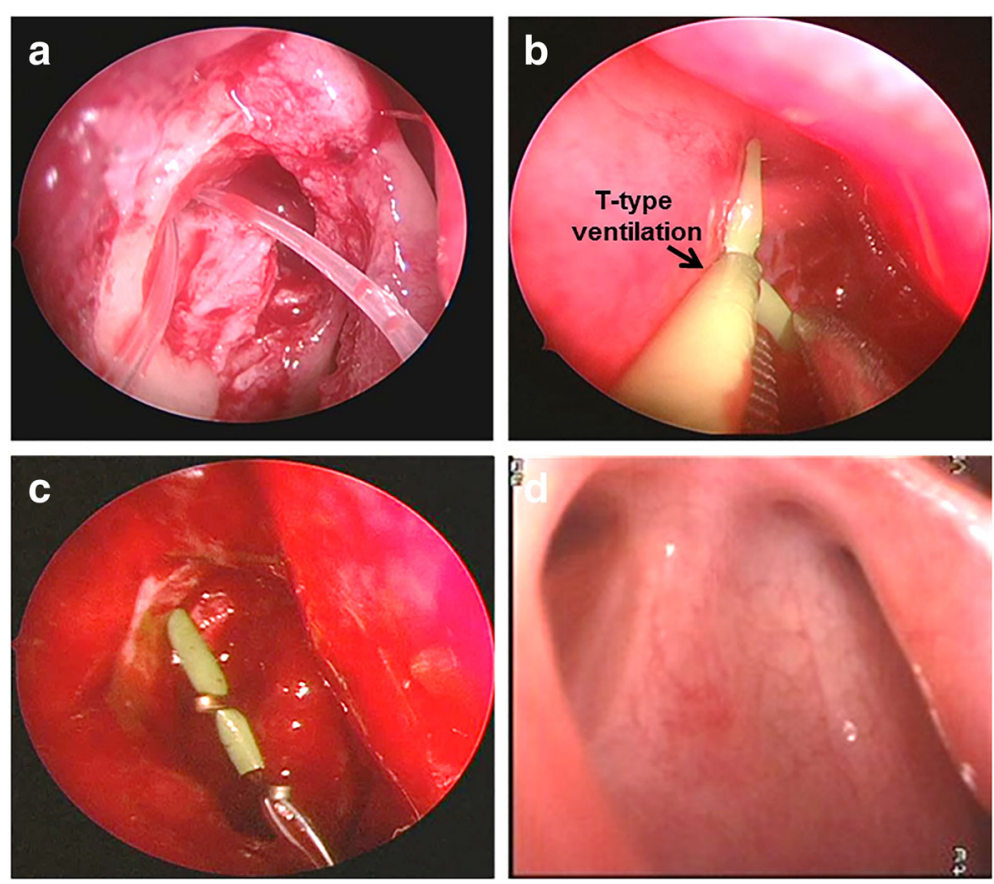

Fig. 1 Surgical techniques. a Silicone tube needles inserted through the inferior and the superior puncta grasped in the nasal cavity (right). b Insertion of the T-type ventilation tube (black arrow) using micro-alligator forceps. T-type ventilation tube was set out of the silicone tube. c A gun-shaped clamp was used to make the T-type tube gradually sliding towards the sac. $\mathbf{d}$ The ostium status in referral visit after removing T-tube 
probes and was clipped with titanium clips to prevent it from falling off. Normal mucosa was reset and make sure there was no active bleeding. One patient who underwent deviated septum surgery was given nasal packing, and the rest were given no nasal packing.

\section{Postoperative disposition}

Postoperatively, the nasal packing material was removed 2 days later, and the patients were given oral antibiotics for 7 days, antibiotic eyedrops for 15 days, nasal steroids for 3 weeks, and oral antihistamines for a week. Patients were followed up every 2 weeks to report any symptoms,

Table 1 General characteristics of patients receiving modified revision EN-DCR

\begin{tabular}{|c|c|c|c|c|c|c|}
\hline Case & Side & $\begin{array}{l}\text { Type of failed } \\
\text { DCR and year }\end{array}$ & $\begin{array}{l}\text { Time from last failed DCR to recurrence } \\
\text { of epiphora (months) }\end{array}$ & Cause(s) of failure & $\begin{array}{l}\text { The times of tube } \\
\text { prolapse }\end{array}$ & $\begin{array}{l}\text { the duration of tube } \\
\text { intubation(weeks) }\end{array}$ \\
\hline 1 & $L$ & $\begin{array}{l}\text { EX } 2006 \\
\text { EN } 2007\end{array}$ & 15 & $\begin{array}{l}\text { Membranous scarring over } \\
\text { ostium }\end{array}$ & 0 & 6 \\
\hline 2 & $\mathrm{R}$ & $\begin{array}{l}\text { EX } 2004 \\
\text { EN } 2006\end{array}$ & 18 & $\begin{array}{l}\text { Wall of lacrimal sac } \\
\text { thickness and fibrosis }\end{array}$ & 1 & 8 \\
\hline 3 & $\mathrm{R}$ & $\begin{array}{l}\text { EX } 2002 \\
\text { EN } 2005\end{array}$ & 37 & Ostium closure & 0 & 15 \\
\hline 4 & $L$ & $\begin{array}{l}\text { EX } 2003 \\
\text { EX } 2005 \\
\text { EN } 2008\end{array}$ & 25 & $\begin{array}{l}\text { Membranous scarring over } \\
\text { ostium }\end{array}$ & 0 & 20 \\
\hline 5 & $L$ & $\begin{array}{l}\text { EN } 2007 \\
\text { EN } 2008\end{array}$ & 8 & Ostium closure & 1 & 14 \\
\hline 6 & $\mathrm{R}$ & $\begin{array}{l}\text { EX } 2007 \\
\text { EN } 2009\end{array}$ & 7 & Wall of lacrimal sac & 0 & 18 \\
\hline 7 & $\mathrm{R}$ & $\begin{array}{l}\text { EX } 2006 \\
\text { EX } 2008 \\
\text { EN } 2010\end{array}$ & 10 & $\begin{array}{l}\text { Membranous scarring over } \\
\text { ostium }\end{array}$ & 2 & 8 \\
\hline 8 & $L$ & $\begin{array}{l}\text { EN } 2009 \\
\text { EN } 2010\end{array}$ & 6 & $\begin{array}{l}\text { Membranous scarring over } \\
\text { ostium }\end{array}$ & 0 & 10 \\
\hline 9 & $L$ & EX 2009 & 9 & Ostium closure & 3 & 13 \\
\hline 10 & $\mathrm{R}$ & $\begin{array}{l}\text { EN } 2009 \\
\text { EN } 2010\end{array}$ & 5 & $\begin{array}{l}\text { Wall of lacrimal sac } \\
\text { thickness and fibrosis }\end{array}$ & 0 & 14 \\
\hline 11 & $L$ & $\begin{array}{l}\text { EN } 2008 \\
\text { EN } 2009\end{array}$ & 12 & $\begin{array}{l}\text { Wall of lacrimal sac } \\
\text { thickness and fibrosis }\end{array}$ & 0 & 18 \\
\hline 12 & $\mathrm{R}$ & EN 2009 & 8 & $\begin{array}{l}\text { Wall of lacrimal sac } \\
\text { thickness and fibrosis }\end{array}$ & 0 & 15 \\
\hline 13 & $\mathrm{R}$ & $\begin{array}{l}\text { EN } 2003 \\
\text { EN } 2005\end{array}$ & 10 & Ostium closure & 2 & 20 \\
\hline 14 & $L$ & $\begin{array}{l}\text { EX } 2007 \\
\text { EN } 2009\end{array}$ & 12 & $\begin{array}{l}\text { Membranous scarring over } \\
\text { ostium }\end{array}$ & 3 & 10 \\
\hline 15 & $L$ & EX 2008 & 6 & $\begin{array}{l}\text { Membranous scarring over } \\
\text { ostium }\end{array}$ & 2 & 15 \\
\hline 16 & $L$ & $\begin{array}{l}\text { EN } 2005 \\
\text { EN } 2009\end{array}$ & 5 & Wall of lacrimal sac & 3 & 13 \\
\hline 17 & $L$ & $\begin{array}{l}\text { EX } 2008 \\
\text { EN } 2010\end{array}$ & 8 & Ostium closure & 1 & 12 \\
\hline 18 & $\mathrm{R}$ & $\begin{array}{l}\text { EN } 2004 \\
\text { EN } 2009\end{array}$ & 10 & Wall of lacrimal sac & 1 & 11 \\
\hline 19 & $\mathrm{R}$ & $\begin{array}{l}\text { EN } 2005 \\
\text { EN } 2008\end{array}$ & 13 & $\begin{array}{l}\text { Membranous scarring over } \\
\text { ostium }\end{array}$ & 2 & 8 \\
\hline 20 & $\mathrm{R}$ & $\begin{array}{l}\text { EX } 2005 \\
\text { EN } 2008\end{array}$ & 16 & $\begin{array}{l}\text { Membranous scarring over } \\
\text { ostium }\end{array}$ & 3 & 6 \\
\hline 21 & $L$ & $\begin{array}{l}\text { EX } 2006 \\
\text { EN } 2008\end{array}$ & 9 & Wall of lacrimal sac & 2 & 6 \\
\hline 22 & $\mathrm{~L}$ & EN 2009 & 7 & Wall of lacrimal sac & 0 & 12 \\
\hline
\end{tabular}


to remove scars, granulation tissue, and possible synechiae under endoscopy until the occurrence of complete local epithelialization. Check whether the T-tube prolapse out of sac and reset the tube if it prolapses. If no partial granulation or adhesion, and smooth stoma was observed in 2 consecutive endoscopies, T-tube was removed. To remove T-tube, silicone tube was cut at innur canthus, and then the T-tube was removed together with the silicone tube under endoscopy. Lacrimal irrigation was carried out weekly for the first month, and twice a month since then. The evaluation of the success was conducted at two time points: 1 , disappearance of patients' symptoms; 2 , no reflux in lacrimal irrigation.

\section{Statistical analyses}

Statistical analyses were performed using GraphPad Prism v5.0 (Graphpad Software Inc.). Two sample test or Chi-square test was used for comparison of qualitative data. A $p<0.05$ was considered to be statistically significant.

\section{Results}

Modified revision EN-DCR was performed on 22 patients ( 7 male and 15 female), and the average age for those patients at the time of revision was 44.5 years (range from 26 to 68 years; SD, 15.1). Of those patients, 15 cases have previously undergone revision EN-DCRs twice, and 2 cases have undergone revision EN-DCRs three times. The patients have previously undergone either EX-DCR or EN-DCR, but the latest surgery of all patients was EN-DCR. The time from last failed DCR to recurrence of epiphora varied from 5 to 37 months with a mean time of 12 months. The main causes of previous failure were membranous scarring over ostium $(8 / 22)$, ostium closure (5/22), or wall of lacrimal sac thickness and fibrosis $(9 / 22)$ (Table 1$)$. In parallel, 22 patients who received conventional EN-DCR were included as a control group. There were no significant differences in age or gender distribution between the experimental and control groups (Table 2). Of these patients, 18 cases have previously undergone revision EN-DCRs twice and 1

Table 2 Comparison of demographics of modified revision EN-DCR and conventional ENDCR Groups

\begin{tabular}{llll}
\hline Variables & Modified EN-DCR & EN-DCR & $P$ Value \\
\hline Age (yrs) & & & \\
Mean & 44.5 & 46.3 & $>0.8^{\mathrm{a}}$ \\
Standard deviation & 15.1 & 16.3 & \\
Gender, n (\%) & & & \\
Male & $7(31.8)$ & $10(45.4)$ & $>0.8^{\mathrm{b}}$ \\
Female & $15(68.2)$ & $12(54.6)$ & \\
\hline${ }^{\mathrm{a}} \mathrm{t}$ test & & & \\
${ }^{\mathrm{C}}$ Chi-square test & & &
\end{tabular}

case has undergone revision EN-DCRs three times. The time from last failed DCR to recurrence of epiphora varied from 6 to 35 months with a mean time of 12.5 months (Table 3 ).

All patients felt the symptom of epiphora, nasal secretions and foreign body sensation. However, these symptoms disappeared after the T-tubes were removed. In the postoperative follow-up visits, 8 patients reported alleviated epiphora before the tube was removed, and 6 patients reported foreign body sensation in nasal cavity or inner canthus with increased nasal secretion. In referral, T-tube was found prolapsed in 9 patients among whom 5 cases prolapsed once, 3 cases prolapsed twice, 1 case prolapsed three times. The tubes were successfully reset whenever prolapses were observed. The duration of tube intubation varied from 6 to 20 weeks, with a mean time of 12.5 weeks. The follow-up time varied from 2 to 3 years with a mean time of 2.3 years. After removing T-tube, 3 patients reported mild epiphora when they felt fatigue in cold weather, but the symptoms disappeared after eyedrops and lacrimal. In the group who underwent modified EN-DCR, 3 patients had complications with 2 cases with eyelid edema which disappeared 1 week after operation and 1 case with appearance of granulation tissue formation surrounding the T-tubes which were cleared under endoscope. In most patients, crusts were found to be formed surround the T-tubes, which were cleared and cleaned with nasal saline in follow-up visits. Eyelid edema and bleeding spots typically recovered 1 week after surgery without interference. In the patients undergoing conventional DCR, 6 patients suffered from eyelid edema and 8 patients reported bleeding spots, and 4 patients experienced epiphora, significantly higher than modified EN-DCR $(90.0 \%$ vs $13.6 \%$, $P<0.0001$ ) (Table 4).

Table 5 summarized surgical outcomes 2 years after surgery. Anatomical success was achieved in 100\% (22/ 22) of modified EN-DCR and 40.9\% (9/22) of conventional EN-DCRs. Functional success was observed in 90.9.0\% (20/22) of modified EN-DCR and 22.7\% (5/22) of EN-DCR. The difference in surgical outcomes between these two surgeries was statistically significant with a two-sample test for equality of proportions with continuity correction $(P<0.01)$. With 44 study patients, the power of this test is $80 \%$ with $\alpha=0.05$ to detect a clinically significant decrease in the success rate of $8 \%$.

\section{Discussion}

In the present study, we slightly modified the approach where an otologic T-tube combined with silicone tube intubation was applied in EN-DCRs. Compared with silicone tube intubation only, this combined approach significantly improved the successful rate. This improvement may be due to the fact that $\mathrm{T}$-tube acts as a support 
Table 3 General characteristics of patients receiving conventional revision EN-DCR

\begin{tabular}{|c|c|c|c|c|}
\hline Case & Side & Type of failed DCR and year & Time from last failed DCR to recurrence of epiphora (months) & Cause(s) of failure \\
\hline 1 & $\mathrm{R}$ & $\begin{array}{l}\text { EX } 2006 \\
\text { EX } 2007\end{array}$ & 16 & Ostium closure \\
\hline 2 & $\mathrm{R}$ & $\begin{array}{l}\text { EX } 2004 \\
\text { EN } 2006\end{array}$ & 22 & Wall of lacrimal sac thickness and fibrosis \\
\hline 3 & $\mathrm{~L}$ & $\begin{array}{l}\text { EN } 2002 \\
\text { EX } 2005\end{array}$ & 19 & Ostium closure \\
\hline 4 & $\mathrm{R}$ & $\begin{array}{l}\text { EX } 2003 \\
\text { EN } 2008\end{array}$ & 25 & Membranous scarring over ostium \\
\hline 5 & $L$ & $\begin{array}{l}\text { EX } 2007 \\
\text { EN } 2008\end{array}$ & 35 & Ostium closure \\
\hline 6 & $\mathrm{~L}$ & $\begin{array}{l}\text { EX } 2007 \\
\text { EN } 2009\end{array}$ & 14 & Wall of lacrimal sac \\
\hline 7 & $\mathrm{R}$ & $\begin{array}{l}\text { EN } 2006 \\
\text { EX } 2008 \\
\text { EN } 2006\end{array}$ & 12 & Membranous scarring over ostium \\
\hline 8 & $L$ & $\begin{array}{l}\text { EX } 2009 \\
\text { EN } 2010\end{array}$ & 8 & Membranous scarring over ostium \\
\hline 9 & $\mathrm{R}$ & $\begin{array}{l}\text { EX } 2009 \\
\text { EN } 2009\end{array}$ & 7 & Wall of lacrimal sac thickness and fibrosis \\
\hline 10 & $\mathrm{R}$ & $\begin{array}{l}\text { EN } 2009 \\
\text { EN } 2010\end{array}$ & 9 & Wall of lacrimal sac thickness and fibrosis \\
\hline 11 & $L$ & $\begin{array}{l}\text { EN } 2008 \\
\text { EN } 2009\end{array}$ & 12 & Ostium closure \\
\hline 12 & $L$ & EN 2009 & 12 & Wall of lacrimal sac thickness and fibrosis \\
\hline 13 & $\mathrm{R}$ & $\begin{array}{l}\text { EN } 2003 \\
\text { EN } 2005\end{array}$ & 11 & Wall of lacrimal sac \\
\hline 14 & $\mathrm{R}$ & $\begin{array}{l}\text { EX } 2007 \\
\text { EN } 2009\end{array}$ & 6 & Ostium closure \\
\hline 15 & $\mathrm{R}$ & EX 2008 & 8 & Membranous scarring over ostium \\
\hline 16 & $L$ & $\begin{array}{l}\text { EN } 2005 \\
\text { EN } 2009 \\
\text { EX } 2008\end{array}$ & 7 & Wall of lacrimal sac \\
\hline 17 & $L$ & $\begin{array}{l}\text { EX } 2008 \\
\text { EN } 2010\end{array}$ & 9 & Ostium closure \\
\hline 18 & $L$ & $\begin{array}{l}\text { EN } 2004 \\
\text { EN } 2007\end{array}$ & 11 & Wall of lacrimal sac \\
\hline 19 & $\mathrm{R}$ & $\begin{array}{l}\text { EN } 2008 \\
\text { EN } 2006\end{array}$ & 12 & Membranous scarring over ostium \\
\hline 20 & $L$ & $\begin{array}{l}\text { EX } 2007 \\
\text { EN } 2009\end{array}$ & 14 & Wall of lacrimal sac \\
\hline 21 & $\mathrm{R}$ & $\begin{array}{l}\text { EX } 2008 \\
\text { EN } 2009\end{array}$ & 8 & Membranous scarring over ostium \\
\hline 22 & $L$ & EN 2007 & 7 & Wall of lacrimal sac \\
\hline
\end{tabular}

Age range: 31-66; Number of male: 8; Number of female: 14

Table 4 Appearance of complications in modified revision EN-DCR and conventional ENDCR Groups

\begin{tabular}{llll}
\hline Complications & $\begin{array}{l}\text { Modified EN-DCR } \\
\text { N (\%) }\end{array}$ & $\begin{array}{l}\text { EN-DCR } \\
\text { N (\%) }\end{array}$ & P Value \\
\hline Present & $3(13.6)$ & $20(90.9)$ & $<0.0001^{\text {a }}$ \\
Absent & $19(86.4)$ & $2(9.1)$ & \\
\hline
\end{tabular}

${ }^{a}$ Chi-square test
Table 5 Outcome for modified revision EN-DCR and conventional EN-DCR Groups

\begin{tabular}{llll}
\hline Variables & $\begin{array}{l}\text { Modified EN-DCR } \\
\text { N (\%) }\end{array}$ & $\begin{array}{l}\text { EN-DCR } \\
\text { N }(\%)\end{array}$ & P Value \\
\hline Anatomical success & $22(100)$ & $9(40.9)$ & $<0.01^{\text {a }}$
\end{tabular}

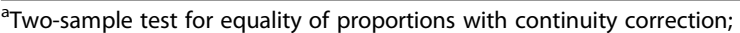
Power $=80 \%$ for $a=0.05$ to detect a decreased success rate of $8 \%$ 
for residual sac mucosa, and it promotes the anastomosis of nasal and lacrimal sac mucosa, which results in spacious and long-lasting channel formation between the sac and nasal cavity, thus easing the ostium stenosis and closure caused by gradual contraction. No severe complications, such as orbital injury, occurred during operation for any of the patients, the incidence of minor postoperative complications such as eyelid edema and bleeding spots were lower than the control group, who have only undergone conventional EN-DCR by the same surgeon.

The closure of newly created ostium is the common cause of failure. It is generally accepted that the size of the excised lacrimal bone and created ostium is important for the long-term outcomes [5]. If the bone window is large enough, the sac is fully exposed, and the anastomosis of nasal and lacrimal sac mucosa flaps is fully achieved, most revision DCRs do not require additional T-tube implants since it prolongs the operation time and adds on additional expense for patients. Moreover, some patients may feel discomfort in the nose and inner canthus caused by T-tube implants. But for patients with high risk of failure such as those with small sac, lacrimal sac mucosa fibrosis and scarring or limited residual sac mucosa, T-tube combined with silicone tube intubation is a better alternative than conventional EN-DCRs.

\section{Conclusions}

Our modified procedure achieved both anatomical success rate and functional success rate with lower occurrence of minor complications. The functional success rate was lower than the anatomical success rate probably due to systolic dysfunction of the remnants of lacrimal sac and the poor siphon function of lacrimal point. While we appreciate the moderate success rate of current EN-DCR, we believe that for the revision ENDCR, T-tube combined with silicone tube intubation needs to be improved due to the two reasons: firstly, it is needed to establish some objective indicators for the combined intubation; secondly, the otologic T-tube we applied was used for the treatment of secretory otitis media but not specifically for DCR. We believe if we can further optimize the material and structure of T-tube to make it more suitable for the application in the lacrimal sac, there will be more widely usage of T-tube in DCR.

Abbreviation

EN-DCRs: Endoscopic dacryocystorhinostomies

\section{Availability of data and materials}

All data generated or analyzed during this study are included in this published article. Raw data contained identifying/confidential patient data which will not be shared.

\section{Authors' contributions}

S. W, T. X, B. F performed the experiments, analyzed and interpreted the data. D. X was a major contributor in writing the manuscript. All authors read and approved the final manuscript.

\section{Ethics approval and consent to participate}

All participants have given informed and written consent. This study was approved by the ethics committee of The Second People's Hospital of Wuxi, and followed the ethical guidelines laid down in the 1975 Declaration of Helsinki.

Consent for publication

All participants have given consent for publication.

\section{Competing interests}

The authors declare that they have no competing interests.

\section{Publisher's Note}

Springer Nature remains neutral with regard to jurisdictional claims in published maps and institutional affiliations.

Received: 16 March 2017 Accepted: 2 August 2017

Published online: 07 August 2017

References

1. Korkut AY, Teker AM, Ozsutcu M, Askiner O, Gedikli O. A comparison of endonasal with external dacryocystorhinostomy in revision cases. Eur Arch Otorhinolaryngol. 2011;268:377-81.

2. Tsirbas A, Davis G, Wormald PJ. Revision dacryocystorhinostomy: a comparison of endoscopic and external techniques. Am J Rhinol. 2005;19: 322-5.

3. Ali MJ, Psaltis AJ, Wormald PJ. Long-term outcomes in revision powered endoscopic dacryocystorhinostomy. Int Forum Allergy Rhinol. 2014;4:1016-9.

4. Choussy O, Retout A, Marie JP, Cozlean A, Dehesdin D. Endoscopic revision of external dacryocystorhinostomy failure. Rhinology. 2010;48:104-7.

5. Hull S, Lalchan SA, Olver JM. Success rates in powered endonasal revision surgery for failed dacryocystorhinostomy in a tertiary referral center. Ophthal Plast Reconstr Surg. 2013;29:267-71.

6. Trimarchi M, Giordano Resti A, Bellini C, Forti M, Bussi M. Anastomosis of nasal mucosal and lacrimal sac flaps in endoscopic dacryocystorhinostomy. Eur Arch Otorhinolaryngol. 2009:266:1747-52.

7. Wormald PJ. Powered endoscopic dacryocystorhinostomy. Otolaryngol Clin N Am. 2006:39:539-49. ix

8. Welham RA, Wulc AE. Management of unsuccessful lacrimal surgery. Br J Ophthalmol. 1987;71:152-7.

9. Takahashi Y, Nakamura Y, Kakizaki H. Dacryoendoscopic findings in the lacrimal passage in failed dacryocystorhinostomy. Ophthal Plast Reconstr Surg. 2013;29:373-5

10. Tsirbas A, Wormald P. Agger nasi cell mucosal autograft for lacrimal sac reconstruction during endonasal dacryocystorhinostomy. Orbit. 2004;23: 105-10

11. Uehara F, Ohba N. External dacryocystorhinostomy combined with mucosal grafting and magnetic resonance imaging. Jpn J Ophthalmol. 2002;46:183-8.

12. Smitha SG, Jagannath B, Mathew AS. Impact of Septal correction on the blood pressure of hypertensive patients with deviated nasal septum. Indian J Otolaryngol Head Neck Surg. 2016;68:46-51. 